\title{
IMPLIKASI HUBUNGAN KYAI DAN TAREKAT PADA PENDIDIKAN PESANTREN
}

\author{
Syahrul A'dam \\ Fakultas Syariah dan Hukum UIN Syarif Hidayatullah Jakarta \\ Jl. Ir. H. Juanda No. 95. Ciputat Tangerang \\ Email: syahrul.adam@uinjkt.ac.id
}

\begin{abstract}
The Implication of the Relationship of Kyai and Tarekat on the Education of Pesantren. Pesantren or Islamic boarding school is the oldest education institution in Indonesia. It is an Indonesian indigenous institution that cannot be found in other places. One of the strengths of Pesantren lies upon the charismatic of the leader of Pesantren, called Kyai, a figure who is highly admired and always be a role model for his students. The Kyai's power is due to his involvement on tarekat, the spiritual practices of Islam, that is growing in Indonesia. However, the situation has changed. Many Kyais today are no longer affiliated with tarekat. As a result, they do not have any certain specialties (Karamah) as owned by Kyais in the past. This condition drives Pesantren to adopt modern methods in its teaching.
\end{abstract}

Keywords: Pesantren, Kyai, Tareqah, Islamic Education in Indonesia

Abstrak: $\quad$ Implikasi Hubungan Kyai dan Tarekat pada Pendidikan Pesantren. Pesantren merupakan lembaga pendidikan Islam tertua di Indonesia. Ia disinyalir sebagai lembaga khas Indonesia dan tidak ditemui di tempat lainnya. Di antara kekuatan pesantren adalah terletak pada kharisma kyai yang menunjukkan sosok yang sangat dikagumi dan senantiasa menjadi tauladan bagi muridmuridnya. Kekuatan kyai di antaranya terletak pada keterlibatannya dalam dunia tarekat-tarekat yang berkembang di Indoensia. Tetapi belakangan ada pergeseran banyak kyai yang tidak lagi berafiliasi pada tarekat, sehingga dia tidak mempunyai kelebihan tertentu (karamah) sebagaimana yang dimiliki para kyai terdahulu. Untuk itu, seiring dengan tidak adanya karomah tersebut, maka pengajaran yang dilakukan pesantren semestinya mengadopsi metode-metode modern.

Kata kunci: Pesantren, Kyai, tarekat, Pendidikan Islam Indonesia

\section{Pendahuluan}

Abdurrahman Wahid dalam salah satu tulisannya mengenai pesantren mengatakan bahwa sejarah penyebaran Islam di Indonesia merupakan hasil perpaduan antara doktrin-doktrin formal Islam dan kultus para wali, yang 
berpuncak pada wali songo, sebagai sisa pengaruh pemujaan orang-orang suci (hermets) dalam agama Hindu. Perwujudan ini, tampak nyata sekali dalam ascetisme $(z u h d)$ yang menjadi warna kental dari kehidupan agama Islam di negeri ini. ${ }^{1}$

Kehidupan model ascetisme ini juga berkembang pesat terutama di dunia pesantren. Pemilihan cara hidup seperti itu, barang kali di samping alasan geneologi keislaman Nusantara yang memiliki corak tersendiri, juga merupakan suatu culture counter terhadap kehidupan umum masyarakat yang sedang di landa krisis moral.

Dari pengamatan sepintas terhadap tradisi yang berkembang di pesantren, tampak bahwa ternyata tradisi pesantren banyak memiliki kemiripan dengan tradisi yang ada dalam tasawuf, dalam hal ini tarekat. Misalnya saja dalam persoalan penghormatan kepada kyai. Sikap hormat kepada kyai adalah ajaran yang mendasar yang ditanamkan kepada santri. Bahkan, kepatuhan itu disinyalir lebih penting dari mencari ilmu itu sendiri.

Tradisi kepatuhan seperti itu, mungkin sulit dipahami dan dimengerti oleh setiap orang. Tetapi, kejadian seperti itu memang ada dalam kelompok-kelompok masyarakat tertentu, termasuk masyarakat pesantren, dengan kyai sebagai pemimpin utamanya. Sebenarnya dalam teori sosiologi tentang model kepemimpinan, Weber telah memberikan teori yang jelas. Dalam teorinya Weber mengatakan bahwa suatu dominasi bisa atas dasar kharisma (charismatic domination) terdapat bila pihak yang berwenang secara pribadi diakui memiliki kharisma akibat kekuatan magis, menerima wahyu, atau juga memiliki sifat kepahlawanan. ${ }^{2}$ Dalam konteks ini benarkah apa yang terjadi di pesantren juga seperti apa yang diteorikan Weber.

${ }^{1}$ Lihat Abdurrahman Wahid, Bunga Rampai Pesantren (Jakarta: Dharma Bakti, 1984), h. 17.

${ }^{2}$ Kharisma oleh Weber didefinisikan sebagai suatu sifat tertentu dari suatu kepribadian seorang individu berdasarkan mana seseorang itu diaggap luar biasa dan diperlakukan sebagai seorang yang mempunyai sifat-sifat ghaib unggul atau paling sedikit dengan kekuatan-kekuatan yang khas dan luar biasa. Lihat Anthony Giddens, Kapitalisme dan Teori Sosial Modern: Suatu Analisis Karya-Karya Tulis Marx, Durkheim dan Max Weber, terj. Oleh Soeheba Kramadibrata dari Capitalism and Modern Social Theory: an Alaysis of Writing of Marx, Durkheim and Max Weber (Jakarta: UIP, 1985), h. 197. Bandingkan juga dengan Haryati Soebadio, Catatan Mangenai Metodologi Penelitian dan Filsafat Ilmu Pengetahuan Khususnnya Bidang Sosial-Budaya (Tidak diterbitkan, 1998), h. 69. 


\section{Penelusuran Sejarah Sosial hubungan Kyai dan Tarekat}

Kyai adalah istilah yang berasal dari jawa yang dipakai untuk tiga jenis gelar yang saling berbeda; pertama, sebagai gelar kehormatan bagi barang-barang yang dianggap keramat, seperti "kyai Garuda kencana" yang dipakai untuk kereta emas yang ada di keraton Yogyakarta; kedua, gelar kehormatan untuk orang-orang tua pada umumnya; ketiga, gelar yang diberikan masyarakat kepada orang agama Islam yang memiliki atau menjadi pimpinan pesantren dan mengajarkan kitab-kitab Islam klasik kepada santrinya. ${ }^{3}$ Kyai dalam pengertian terakhir ini dalam bahasa Sunda disebut "Ajengan". Berangkat dari beragamnya penggunaan istilah kyai tersebut, maka tidak benar, menurut Aliy As'ad, ${ }^{4}$ bila mengatakan bahwa kyai mesti ahli agama Islam. Ini sama dengan gebyah uyah, sama halnya dengan penarikan kesimpulan yang dari premis-premis yang salah; seperti manusia kalau makan yang bergerak rahang bawahnya, kambing bila makan yang bergerak rahang bawahnya, begitu juga halnya dengan sapi dan kerbau, lantas diambil kesimpulan bahwa semua binatang kalau makan yang bergerak adalah rahang bawahnya. Kemudian bagaimana dengan buaya yang kalau makan rahang yang bergerak adalah yang atas.

Dalam menjelaskan hal tersebut, Aliy As'ad menambahkan bahwa gelar kyai digunakan dalam tiga dimensi; pertama, kyai ulama seperti Kyai Hasyim Asy'ari, Kyai Mahfudz al-Termasi dan lain-lainnya; kedua, kyai sebutan, artinya sebutan kepada yang mempunyai kelebihan, mereka juga mempunyai pendukung untuk mengakui kelebihannya; ketiga, kyai aku-akuan yakni kyai yang sebetulnya tidak mempunyai kelebihan spiritual apa-apa. ${ }^{5}$

Untuk mengetahui siapa yang layak disebut kyai atau yang tidak, mestinya harus ada parameter yang jelas, supaya tidak terjebak pada penggunaan gelar pada orang yang tidak pantas digelari dengan gelar tersebut. Menurut Abuddin Nata ${ }^{6}$ bahwa kyai secara keilmuan mempunyai ciri-ciri antara lain, (1) menguasai ilmu agama secara mendalam, (2) keilmuan yang dimiliki

${ }^{3}$ Lihat Zamakhsyari Dhofier, Tradisi Pesantren: Studi tentang Pandangan Hidup Kiai (Jakarta: LP3ES, 1994), h. 55

${ }^{4}$ Lihat Aliy As'ad, "Pendahuluan terjemahan Kitab Ta’lim al-Muta’allim” dalam Aliy As'ad, Bimbingan bagi Penuntut Ilmu (teremahan Tálim al-Muta'allim) (Kudus: Menara Kudus, tanpa tahun), h. VII.

${ }^{5}$ Lihat Aliy As'ad, "Pendahuluan terjemahan Kitab Ta'lim al-Mutaallim, h. VII.

${ }^{6}$ Abuddin Nata, Katerangan pada Kuliah Sejarah Sosial dan Intelektual Pendidikan Islam II, tanggal 1 Mei 2000 . 
telah mendapat pengakuan dari masyarakat sekelilingnya, (3) menguasai kitab kuning dengan matang, (4) taat beribadah kepada Allah Swt., (5) mempunyai kemandirian dalam bersikap, (6) tidak mau "mendatangi" penguasa, (7) mempunyai geneologi ke-kyai-an, (8) memperoleh ilham dari Allah. Bila memenuhi kreteria tersebut, maka layaklah seseorang disebut kyai dalam pengertian yang lazim.

Sedangkan istilah kedua, tarekat, secara bahasa berasal dari bahasa Arab thariqah yang mempunyai arti jalan. ${ }^{7}$ Sedangkan secara terminologi tarekat adalah suatu metode atau cara yang harus ditempuh seorang salik (orang yang menempuh kehidupan sufistik), dalam rangka membersihkan jiwanya sehinga dapat mendekatkan diri kepada Allah swt. Metode tersebut pada mulanya dilakukan oleh seorang sufi besar, kemudian diikuti oleh muridmuridnya yang akhirnya membentuk suatu jamiyyah (organisasi). ${ }^{8}$

Pada mulanya organisasi tarekat ini muncul di daratan Timur Tengah. Setelah itu, menyebar ke seluruh pelosok dunia, tidak terkecuali Indonesia. Wacana tarekat di Indonesia erat kaitannya dengan wacana masuknya Islam ke Indonesia. Menurut beberapa pendapat, di antaranya yang disebutkan Azyumardi Azra bahwa Islam masuk ke Indonesia atau Nusantara dibawa oleh para sufi yang gencar mengadakan pengembaraan, terutama sejak abad ke13, setelah keruntuhan Bahgdad atas Mongolia. Para sufi pengembara, waktu itu, memainkan peran yang cukup penting dalam memelihara keutuhan Dunia Muslim dengan menghadapi tantangan kecenderungan pengepingan kawasan-kawasan kekhalifaan ke dalam wilayah-wilayah linguistik Arab, Persi dan Turki. Pada masa ini tarekat sufi secara bertahap menjadi institusi yang stabil dan disiplin, dan mengembangkan afiliasi dengan kelompok-kelompok dagang dan kerajinan tangan yang turut membentuk masyarakat urban. ${ }^{?}$

Dikatakan bahwa tarekat-tarekat pada mulanya mendapat tempat di kalangan istana. Kemudian secara pelan-pelan mulai merembes ke kalangan

${ }^{7}$ Lihat Atabik Ali, Ahmad Zuhdi Muhdlor, Qamus Krapyak al-Ashri Arabi-Indonesi (Yogyakarta: Yayasan Ali Maksum Pondok Pesantren Krapyak Yogyakarta, 1996), h. 1231.

${ }^{8}$ Lihat Mirce Aliade (ed.), The Encyclopedia of Islam, Vol. 14 (New York: Macmillan Publishing Co. 1987), h. 342; Lihat juga Ahmad Tafsir, "Tarekat dan Hubungannya dengan Tasawuf" dalam Harun Nasution (ed.), Tarekat Qadiriyah Naqsabandiyah: Sejarah Asal Usul dan Perkembangannya (Tasik Malaya: IAILM, 1990), h. 129; Amin Abdullah, Studi Agama: Normativitas atau Historis (Yogyakarta: Pustaka Pelajar, 1996), h. 153.

${ }^{9}$ Lihat Azyumardi Azra, Jaringan Ulama Timut Tengah dan Kepulauan Nusantara Abad XVII dan XVIII: Melacak Akar-Akar Pembaruan Pemikiran Islam di Indonesia (Bandung: Mizan, 1994, 33. 
masyarakat awam. Menjelang abad ke-18, berbagai macam bentuk tarekat telah mulai tersebar di Nusantara. Ini terjadi karena murid-murid yang belajar di Haramain mulai kembali ke tanah Air dan mengajarkan tarekat yang pernah dipelajarinya selama di sana. Di antara tarekat-tarekat itu adalah, tarekat Syattariyah, tarekat Naqsabandiyah, tarekat Qadiriyah, tarekat Qadiriyah wa Naqsabandiyah, tarekat Syadziliyah, tarekat Sammaniyah, tarekat Tijaniyah dan tarekat Kubrawiyah.

Secara singkat, tarekat-tarekat tersebut dapat dideskripsikan berikut; Tarekat Syattariyah adalah tarekat yang dibawah pertama kali oleh Syekh Abd Allah al-Syattari (w. 1415);10 Tarekat Qadiriyah adalah tarekat yang disnisbatkan kepada Syekh Abd al-Qadir al-Jailani (w. 1166); ${ }^{11}$ Tarekat Syadziliyah adalah terkat yang dinisbatkan kepada Syekh Abu al-Hasan alSyadzili dari Maroko (w. 1258); ${ }^{12}$ Tarekat Naqsabandiyah dengan mengambil nama dari Syekh terbesarnya yaitu Syekh Baha'u al-Din Naqsaband dari Bukhara (w. 1390); ;3 Tarekat Tijaniyah merupakan tarekat yang didirikan oleh Syekh Abbas Ahmad ibn al-Tijani dari al-jazair (w. 1815); ${ }^{14}$ Tarekat Qadiriyah wa Naqsabandiyah didirikan oleh Ahmad Khatib al-Sambasi yang merupakan penggabungan dari tarekat Qadiriyah dan tarekat Naqsabandiyah; ${ }^{15}$ Tarekat Kubrawiyah adalah tarekat yang didirikan oleh Najmuddin Kubra; ${ }^{16}$ Tarekat Sammaniyah adalah didirikan oleh Muhammad Samman dari Madinah.

Dalam melihat konteks hubungan tarekat dan kyai, pesantren menjadi elenmen penting. Perlu diketahui bahwa pesantren merupakan salah satu tradisi agung (great tradition) di Indonesia. Kemunculan pesantren itu disinyalir sebagai usaha untuk mentransmisikan keilmuan Islam tradisional sebagaimana yang terdapat dalam kitab-kitab klasik yang ditulis oleh para ulama beberapa abad silam.

${ }^{10}$ Lihat Hawas Abdullah, Perkembangan Ilmu Tasawuf dan Tokoh-tokohnya di Nusantara (Surabaya: al-Ikhlas, tanpa tahun), h. 49.

${ }^{11}$ Keterangan lebih lanjut baca J. Spencer Trimingham, Madzhab Sufi, terj. Oleh Luqman Hakim dari The Sufi Orders (Bandung: Pustaka, 1999)

${ }^{12}$ Lihat Fadhlullah Haeri, Belajar Mudah Tasawuf, terj. oleh Muhammad Hasyim Assagaf dari The Elements of Sufism (Jakarta: Lentera, 1999), cet. Kedua, h. 27.

${ }^{13}$ Lihat Imran Abu Bakar, Disekitar Masalah Thariqat (Naqsabandiyah) (Kudus: Menara Kudus, 1984), h. 25; keterangan lebih lanjut bandingkan dengan Fuad Said, Hakikat Tarekat Naqsabandiyah (Jakarta; Pustaka al-Husna, 1994).

${ }^{14}$ Lihat Martin van Bruinessen, "The Origins and Development of Sufi Orders (Tarekat) in Shautheast Asia” dalam Studia Islamika, vol. 1, no. 1, 1994 (Jakarta: PPIM IAIN Jakarta), h. 17.

${ }^{15}$ Lihat Martin Van Brunissen, Tarekat Naqsabandiyah, h. 89.

${ }^{16}$ Lihat Martin Van Bruinessen, Kitab Kuning, h. 223. 
Selain menjadi pusat pengajaran keilmuan Islam, pesantren juga menjadi pusat gerakan tasawuf, dalam hal ini tarekat. Menurut Zamakhsyari Dhofiier, sebenarnya yang menjadi landasan pengajaran tarekat di pesantren adalah ajaran-ajaran nabi sendiri, terutama tentang tiga pilar ajaran Islam yaitu, Islam, iman dan ihsan. ${ }^{17}$ Orang yang telah mengakui Islam sebagai agamanya disebut Muslim, tetapi belum tentu Muslim itu mu'min, kecuali setelah disertai dengan keimanan. Sebab iman merupakan ketaatan dan keterikatan secara terus menerus dengan Tuhan. Sedangkan ihsan merupakan tingkatan yang lebih tinggi lagi, karena ihsan berupa kemampuan untuk menembus ke dalam inti wahyu ketuhanan. Ketiga pilar tersebut kalau ditarik pada bidang keilmuan akan melahirkan apa yang dikenal dengan syariah, tauhid dan akhlak (tasawuf). Jadi, antara tiga pilar tersebut, sebenarnya bukanlah sesuatu yang harus dibedakan, tetapi harus menjadi satu kesatuan.

Ihsan sendiri, menurut Hasyim Asy'ari dalam Nurcholish Madjid, yang kemudian dipraktekkan melalui ajaran tarekat untuk dapat menangkap wawasan tentang kebulatan dan kebenaran dalam segala dimensinya. Kemampuan untuk menangkap kebenaran yang utuh ini merupakan sesuatu yang sangat sulit dicapai manusia. Sebabnya adalah kebenaran dalam dimensinya yang utuh itu, justru dalam dirinya mengandung paradoks, dan orang dapat belajar menangkap keutuhan kebenaran itu dengan melakukan latihan-latihan dalam melihat paradoks-paradoks dan berusaha menangkap hakikat yang ada dibalik penampakan lahiriyah tersebut. ${ }^{18}$

Landasan teologis penangkapan paradoksal seperti itu, disebutkan dalam al-Qur'an pada kisah antara Nabi Musa dengan seseorang yang dilukiskan sebagai hamba Allah yang memperoleh ilmu ladunni yaitu ilmu yang langsung diberikan oleh Allah, tanpa melalui proses belajar. Tokoh ini dalam literatur kesufian dikenal dengan Nabi Khidlir (al-Khidhir), yang agaknya merupakan nama perlambang akan kebenaran yang selalu hijau dan tidak pernah mati. Latihan-latihan untuk dapat mencapai seperti yang dicapai khidir itu yang dikenal dengan tarekat.

Hanya saja perlu diketahui bahwa tarekat yang dipahami di pesantren

${ }^{17}$ Lihat Zamakhsyari Dhofier, Tradisi Pesantren: Studi tentang Pandangan Hidup Kiai (Jakarta: LP3ES, 1994), h. 136.

${ }^{18}$ Lihat Nurcholish Madjid, "Islam, Iman dan Ihsan Sebagai Trilogi Ajaran Ilahi” dalam Budhy Munawar Rahman, Kontekstualisasi Doktrin Islam dalam Sejarah (Jakarta: Mizan, 1995), h. 478. 
tidak hanya menunjuk pada tarekat yang dipahami selama ini, ${ }^{19}$ tetapi juga dipahami sebagai suatu kepatuhan secara ketat kepada peraturan-peraturan syariah Islam dan mengamalkannya dengan sebaik-baiknya, baik yang bersifat ritual maupun sosial; yaitu dengan menjalankan praktek-praktek wira'i. ${ }^{20}$ Sebenarnya pemahaman seperti ini lebih identik pada tasawuf pada masa awal sebelum timbulnya organisasi-organisasi tarekat.

Dengan demikian ada dua bentuk tarekat yang berlaku di pesantren, pertama tarekat yang diperaktekkan menurut cara yang dilakukan oleh organisasi-organisasi tarekat, dan kedua, tarekat yang dipraktekkan menurut cara-cara diluar ketentuan organisasi tarekat. Dalam kategori pertama tidak semua pesantren, khususnya kyai, menjadi penganut tarekat tertentu, tetapi dalam pemahaman kedua barang kali dapat dipastikan bahwa semua pesantren menjadi pengamal tarekat.

Terlepas dari kontroversi pemahaman tarekat di atas, yang jelas seorang kyai yang menjadi pemimpin tarekat, dalam pengertian yang pertama, pada mulanya merupakan seorang murid yang telah memperoleh ijazah atau limpahan wewenang untuk tugas itu dari guru atasannya dalam susunan mata rantai (silsilah) ${ }^{21}$ tarekat. Sebaliknya, pengikut atau murid yang belum mendapatkan ijazah, tidak diperkenankan mengajarkan kepada orang lain. Pelanggaran terhadap ketentuan ini dianggap sebagai pengkhianatan kepada baiat (janji suci) yang telah diucapkannya ketika pertama kali ia memasuki dunia tarekat. ${ }^{22}$

19 Tarekat adalah suatu metode atau cara yang harus ditempuh seorang salik (orang yang menempuh kehidupan sufistik), dalam rangka membersihkan jiwanya sehinga dapat mendekatkan diri kepada Allah swt. Metode tersebut pada mulanya dilakukan oleh seorang sufi besar, kemudian diikuti oleh murid-muridnya yang akhirnya membentuk suatu jamiyyah (organisasi). Lihat Mirce Aliade (ed.), The Encyclopedia of Islam, Vol. 14 (New York: Macmillan Publishing Co. 1987), h. 342; Lihat juga Ahmad Tafsir, "Tarekat dan Hubungannya dengan Tasawuf” dalam Harun Nasution (ed.), Tarekat Qadiriyah Naqsabandiyah: Sejarah Asal Usul dan Perkembangannya (Tasik Malaya: IAILM, 1990), h. 129; Amin Abdullah, Studi Agama: Normativitas atau Historis (Yogyakarta: Pustaka Pelajar, 1996), h. 153.

${ }^{20}$ Lihat Zamakhsyari Dhofier, Tradisi Pesantren: Studi tentang Pandangan Hidup Kiai (Jakarta: LP3ES, 1994), h. 136.

${ }^{21}$ Ijazah dan silsilah adalah akibat logis dari adanya doktrin kerahasiaan yang ada dalam tarekat, artinya seorang pengikut tarekat harus merahasiakan ajaran-ajaran tarekat yang diikutinya kepada orang lain, kecuali kalau sudah memenuhi kualifikasi-kualifikasi tertentu. Doktrin tersebut bertitik tolak dari adanya keyakinan bahwa Nabi Muhammad datang ke dunia ini dengan membawa dua macam risalah, pertama yang diperuntukkan kepada semua kaum muslim dan yang kedua hanya dikhususkan kepada orang-orang tertentu saja, dalam hal ini Ali bin Abi Thalib.

${ }^{22}$ Pembaiatan adalah sebuah prosesi perjanjian antara seorang murid terhadap seorang mursyid. Seorang murid menyerahkan dirinya untuk dibina dan dibimbing dalam rangka membersihkan 
Mursyid dalam tarekat menempati kedudukan yang sangat urgen. Sebab mursyid berkedudukan sebagai perantara (washilah) antara sang murid dengan Tuhannya. Konsep wasilah ini yang mendatangkan banyak kritikan dari para "pembenci" tarekat. Kritikan seperti itu, menurut Zamakhsyari Dhofier, timbul karena mereka tidak mempelajari konsep-konsepnya secara mendalam. Dalam usaha menangkis kritikan tersebut, Kyai Musthafa Bisri selaku pengikut tarekat memberikan illustrasi tentang wasilah sebagai berikut:

Allah ta'ala Maha Mengetahui dan Maha Mendengar. Saudara jangan mengira bahwa tawassul kepada Allah Ta'ala dengan Nabi-Nabi atau wali-wali itu sama dengan memohon kenaikan tingkat kepada pihak atasan dengan perantaraan kepala kantor saudara.

Pengertian tawassul yang demikian itu tidak benar. Sebab berarti mengalihkan pandangan terhadap yang dituju (pihak atasan), beralih kepada perantara sehingga di samping mempunyai kepercayaan terhadap kekuasaan pihak atasan, saudara juga percaya kepada kekuasaan pihak peranyata. Tawaasul kepada Allah ta'ala tidak demikian halnya.

Kalau saudara ingin contoh tawassul kepada Allah dengan Nabi-Nabi atau wali-wali, coba saja perhatikan misal di bawah ini. Ada seorang majikan yang kaya raya dan memiliki perusahaan besar. Dia mempunyai beberapa orang pembantu yang paling dipercaya dalam mengendalikan perusahaannya. Saya ingin diterima menjadi pekerja dalam perusahaannya. Kebetulan saya kenal dengan salah seorang pembantu majikan tersebut untuk keperluan lamaran pekerjaan; Saya diantar oleh pembantu majikan yang saya kenal tadi. Kepada majikan itu saya sampaikan maksud saya harapan dapat membantu saya agar lamaran saya mendapat perhatian cukup dari sang majikan. Coba pikirkan.

Kepada siapa sebenarnya saya mengajukan lamaran saya? Kemudian apakah sia-sia saja saya diantar oleh teman saya tersebut sewaktu saya menghadap sang majikan? ${ }^{23}$

\footnotetext{
jiwanya, dan mendekatkan diri kepada Tuhannnya dengan mengajarkan dzikir kepadanya. Prosesi pembaiatan antara satu tarekat dengan tarekat lainnya berbeda-beda. Ada yang dilakukan secara individual (fardiyyah) dan ada juga yang dilakukan secara kalektif (jamaiyyah). Dalam tarekat Qasiriyah wa Naqsabandiyah misalnya prosesi dilakukan setelah calon murid mengetahui terlebih dahulu hal ihwal tarekat tersebut, terutama menyangkut kewajiban-kewajiban yang harus dilaksanakannya. Lihat Harisuddin Aqib, al-Hikmah: Memahami Teosofi Tarekat Qadiriyah wa Naqsabandiyah (Surabaya: Bina Ilmu, 1998), h. 95-101.

${ }^{23}$ Lihat Zamakhsyari Dhofier, Tradisi Pesantren, h. 138.
} 
Dari uraian di atas tampak jelas bahwa tawassul sebenarnya lebih sebagai "kawan dalam perjalanan" dibandingkan sebagai "campur tangan" dalam memempuh perjalanan menuju Tuhan. Kalau memang demikian, sisi mananya yang bertentangan dengan ajaran tauhid?

Sebagai konsekuensi logis dari paham tersebut diatas, kemudian muncul konsep barakah dari mursyid yang mempunyai karomah yang dikenal dengan wali. ${ }^{24}$ Sehingga ketika ia meninggal, kuburannya menjadi sasaran kunjungan orang-orang yang ingin mendapatkan berkah. Berkah itu diperlukan karena disadari bahwa intuisi tasawuf dapat berjalan sejajar dengan subyektivisme orang sebagaimana umumnya akibat tekanan penghayatan ketuhanan yang serba imanent, maka perlu diadakan pengaturanpengaturan. Pengaturan-pengaturan seperti itu hanya bisa dilakukan oleh seseorang yang benar-benar mengerti persoalan dan ia dijadikan satusatunya sumber otoritatif kerohanian untuk periode dan kelompok tertentu. Untuk menghindari dari subyektivisme murid harus mematuhi dan setia kepada ajaran guru yang bersangkutan agar tetap terpelihara dan terjaga dari bahaya subyektivisme diri sendiri.

Seorang wali mempunyai pengaruh yang sangat kuat dalam memelihara para pengikutnya, baik sewaktu masih hidup maupun setelah meninggal, bahkan diyakini bahwa ia akan hidup setelah meninggal dan memberikan bimbingan dari alam ghaib. Adanya perasaan hubungan yang intim dengan para wali akan memberikan kehangatan dan intensitas dalam ritus-ritus yang dilakukan oleh kelompok tarekat tersebut. ${ }^{25}$ Sejalan dengan

\footnotetext{
${ }^{24}$ Ada sebuah hadis yang terkenal berkenan dengan wali Allah, yaitu sebagai berikut: “...Seusai Rasulullah bersembahyang, beliau menghadap ke arah orang banyak, lalu bersabda,"Hai sekalian orang, dengarkanlah, fikirkanlah dan ketahuilah bahwa Allah punya hamba-hamba yang tidak tergolong para nabi ataupun para syuhada' berebut dengan mereka dalam kedudukan dan ketaatan mereka kepada Allah." Kemudian tampil seorang Arab Badui dari kalangan orang-orang yang jauh (sederhana), mengarahkan tangannya kepda Rasulullah saw., dan berkata, "Hai Nabi Allah, mereka itu dari kalangan manusia pada umumnya, bukan nabi dan bukan pula syuhada', namun para nabi berebut dengan mereka dalam kedudukan dan kedekatan kepda Allah? Gambarkanlah kepada kami sifat-sifat mereka itu". Wajah Rasulullah berseri-seri oleh pertanyaan orang Arab Badui itu, lalu bersabda, "Mereka itu segolongan orang dari kalangan manusia sederhana dan kabilah-kabilah biasa; sesama mereka ada kaitan keterlibatan dekat, namun mereka saling mencitai demi Allah dan saling membantu. Di hari kiamat nantiAllah akan menyediakan bagi mereka mimbar-mimbar dari cahaya terang, dan pakaian mereka cahaya terang. Di hari kiamat semua orang merasa ketakutan, namun mereka tidak. Mereka itulah para wali Allah yang tiada rasa takut pada mereka dan tidak pula mereka merasa kuatir" (H.R. Imam Ahmad). Lihat, Imam Ahmad b. Hambal, Musnad Imam Ahmad, dalam CD ROM Hadits Versi 102.

${ }^{25}$ Lihat Nurcholish Madjid, Bilik-Bilik Pesantren: Sebuah Potret Perjalanan (Jakarta: Paramadina, 1997), h. 64.
} 
itu, tradisi ziarah ke kuburan wali menjadi tradisi yang berkembang pesat dalam kalangan tarekat, sehingga nampak sebagai "pemujaan" kepada kuburan.

\section{Kyai dan Tarekat: Implikasi pada Pendidikan Pesantren}

Sebagaimana disinyalir sebelumnya bahwa pada awal-awal keberadaan pesantren hampir seluruh kyai adalah pengamal tarekat, sehingga mereka mempunyai banyak keistimewaan-keistimewaan yang ada pada dirinya. Akhirnya, kyai dianggap sebagai seorang wali yang dapat memberikan berkah, serta dapat membuat sesuatu yang khariqul 'adah dengan izin Allah Tảala.

Pemahaman seperti itu, berimplikasi pada pola pendidikan yang dilaksanakan di pesantren. Pendidikan yang dilaksanakan mengambil pola pendidikan yang ada dalam tarekat. Artinya kyai adalah menjadi figur sentral yang dianggap dapat memberikan berkah dengan karomahnya, sehingga ia menjadi otoritas tunggal yang menjadi rujukan pembelajaran. Kata-kata dan prilakunya harus dijadikan tauladan dan tidak boleh dibantah atau disalahkan. Oleh karena itu, kepatuhan kepada kyai dianggap lebih penting dari belajar itu sendiri.

Dalam konteks ini, banyak sekali kejadian-kejadian yang mengindikasikan kenyataan tersebut. Misalnya ada seorang anak yang nyantri di pondok pesantren kyai A, dari semenjak masuk pesantren, santri tersebut tidak diperkenenakan mengikuti pengajian sebagaimana santri lainnya. Ia hanya diperintahkan untuk merawat ternak kyai itu. Namun, ketika santri itu disuruh pulang dan mendirikan pesantren di daerah tertentu, ternyata ia mampu menguasai pelajaran yang dipelajari di pesantren yang ia sendiri tidak pernah mempelajarinya, bahkan kemampuannya mengalahkan santri lain yang belajar dengan tekun sekalipun.

Kisah-kisah seperti ini menjadi sangat masyhur dikalangan pesantren. Hal itu, disebabkan kyai mengetahui segala yang paradoks yang menjadi tampak sangat aneh bagi orang yang tidak dapat menangkapnya. Akibatnya, pendidikan akhlak dan etika belajar menjadi sesuatu yang harus dipelajari sebelum mempelajari pelajaran yang lain. ${ }^{26}$ Perlu diketahui

${ }^{26}$ Kitab-kitab etika dan akhlak yang dipelajari di pesantren antara lain: Ta'lim al-Mutáallim, Wasaya, Akhlaq li al-Banin, Akblaq li al-Banat, Irsyad al-Ibad, Nashaih al-Ibad, Ihya Ulum al-Din, Sair al-Salikin, Bidayah al-Hidayah, Maraq al-Ubudiyah, Hidayah al-Salikin, Minhaj al-Abidin, Siraj 
bahwa kitab-kitab etika belajar, hampir seluruhnya, ditulis karena adanya kesenjangan yang ada waktu itu antara ilmu yang dipelajari dengan etika yang ditunjukkan. Kesenjangan tersebut mengundang keprihatinan yang mendalam untuk menyusun kitab-kitab seperti itu. Di antara yang menjadi ajaran sentralnya adalah bagaimana etika murid terhadap gurunya. Hampir semua kitab itu mengajarkan hubungan kepasrahan total kepada kyai, sebab kyai adalah orang tua kedua setelah orang tua, bahkan kedudukannya lebih mulia. Sebab orang tua hanya memelihara badan saja, sedangkan kyai yang telah mengisi mental spiritual. Hal seperti ini sangat kental dalam wacana tasawuf yang masyhur dengan ungkapan "al-muridu fi yadi al-ustadz ka almayyiti yadi man yaghsiluhu" (seorang murid di tangan guru tak ubahnya sebagaimana orang mati di tangan orang yang memandikannya).

Pola hubungan seperti ini, dapat dilihat dari kitab-kitab etika belajar yang banyak bernuansa sufistik., misalnya saja kitab Ta’lim al-Muta'allim thuruq al-Ta'allum karya al-Zarnuji. Mengenai sikap murid kepada guru ini, al-zarnuji dengan mengutip kata-kata Ali bin Abi Thalib mengatakan, "Ana abdu man allamani harfan wahidan" (Aku adalah hamba orang yang telah mengajari saya wuruf satu). Selanjutnya dikembangkan etika hubungan yang harus dilaksanakan murid antara lain (1) dengan tidak berjalan di depannya, duduk ditempatnya, (2) tidak memulai mengajak bicara kecuali atas perkenannya, (3) berbicara macam-macam di depannya, (4) tidak menanyakan hal-hal yang membosankannya, (5) tidak boleh mengetuk pintunya ketika guru belum datang dan (6) cukuplah dengan sabar menanti di luar hingga ia sendiri yang keluar dari rumah. ${ }^{27}$

Dengan etika tersebut, tampak bahwa pola pembelajaran yang dikembangkan menjadi teacher centred bukan student centred. Ada pertanyaan yang harus patut diajukan dalam mencermati kenyataan tersebut antara lain, masih cocokkah pola hubungan kyai-santri (guru-murid) seperti itu diterapkan dalam konteks zaman sekarang? Lalu, apakah kyai yang sekarang juga masih mempunyi tingkat kualifikasi dalam bidang kesalehan seperti kyai-kyai waktu dulu? Dalam hal ini penulis melihat kedua hal tersebut

al-Thalibin, Hilam dan Syarah Hikan, Hidatyah al-Adzkiya', Kifayah al-Atqiya' Risalah al-Mu'awanah, Nashaih al-Diniyah, Adzkar. Lihat Van Bruinessen, Kitab Kuning Psantren dan Tarekat : TradisiTradisi Islam di Indonesia (Bandung: Mizan, 1999), cet. Ke III, h. 163.

${ }^{27}$ Lihat al-Zarnuji, Ta'lim al-Muta'allim Thariq al-Ta'allum, terj. Oleh Aliy As'ad (Kudus: Menara Kudus, 1978), h. 8. 
sebagai sesuatu yang tak terpisahkan. Artinya ketika seorang kyai masih menggunakan pola seperti yang pertama (taecher centred), maka kyai juga harus mempunyai kualifikasi kesalehan yang tinggi sehingga dapat memberikan berkah kepada santrinya. Namun, kalau tidak bisa seperti itu, maka pola pengajaran harus menggunakan pola kedua (student centred) atau student-teacher centred.

Penulis melihat, ketika prasyarat tidak dapat dipenuhi sementara kyai masih memakai pola yang pertama, maka itu hanya merupakan "arogansi" kyai yang ingin mempertahankan kharisma seperti yang pernah terjadi kepada para pendahulunya. Tetapi, sebenarnya itu tidak bisa dilakukan pada dirinya, kecuali dengan melakukan "pemaksaan" kepada santri dan lingkungan masyarakat dengan gaya yang sangat "otoriter".

Selain itu, pola hubungan kharismatik seperti itu menjadi kelemahan pesantren. Kesetiaan yang bersikap pribadi sukar diterjemahkan dalam menjadi kesetiaan kepada lembaga; ini dapat dibuktikan dengan banyaknya pesantren yang "gulung tikar" karena ditinggal oleh kyainya. ${ }^{28}$ Namun demikian, hal itu juga bisa menjadi kelebihan, bila sang kyai mempunyai pikiran perubahan, dalam waktu itu perubahan dapat terjadi tanpa harus menunggu waktu yang lama.

\section{Penutup}

Dari uraian tersebut di atas, penulis melihat pentingnya rekonstruksi pemahaman tentang otoritas kyai ketika ia tidak lagi menjalankan tata cara hidup ke-tarekat-an. Sebab ia tidak lagi mempunyai karomah seperti yang ada pada para kyai yang tekun menempuh jalan tersebut.

Pola pendidikan pesantren seharusnya mengalami perubahan dari pola "tradisional" kepada pola-pola "modern". Interaksi santri dengan dunia yang terus melaju pesat, nampaknya tidak mampu lagi dihadapi hanya dengan pola pengajaran keagamaan semata, tetapi penting rasanya juga dibekali dengan ilmu-ilmu keterampilan yang dapat mendukung pergumulan mereka dengan dunianya.

Akhirnya, kyai seharusnya mulai melihat kembali dan mengakui dengan jujur tentang kemampuan dirinya. Ketika ia tidak lagi sangggup

${ }^{28}$ Lihat Abdurrahman Wahid, Bunga Rampai Pesantren, h. 19. 
menjadi "begawan", maka ia seharusnya mampu sharing ide dengan kelompok masyarakat lainnya dan meninggalkan jubah "kharisma semu" yang sedang dikenakannya.

\section{Pustaka Acuan}

Abdurrahman Wahid, Bunga Rampai Pesantren (Jakarta: Dharma Bakti, 1984). Abuddin Nata, Katerangan pada Kuliah Sejarah Sosial dan Intelektual Pendidikan Islam II, tanggal 1 Mei 2000

A.G. Muhaimin, "Pesantren and Tarekat in The Modern Era: An Account on The Transmission of Traditional Islam in Java", dalam Studia Islamika, Vol. 4 No. 1, 1997 (Jakarta: PPIM IAIN Jakarta).

Ahmad Tafsir, "Tarekat dan Hubungannya dengan Tasawuf", dalam Harun Nasution (ed.), Tarekat Qadiriyah Naqsabandiyah: Sejarah Asal Usul dan Perkembangannya (Tasik Malaya: IAILM, 1990).

Aliy As'ad, "Pendahuluan terjemahan Kitab Ta'lim al-Muta'allim" dalam Aliy As'ad, Bimbingan bagi Penuntut Ilmu (teremahan Ta'lim al-Muta'allim) (Kudus: Menara Kudus, tanpa tahun).

Amin Abdullah, Studi Agama: Normativitas atau Historis (Yogyakarta: Pustaka Pelajar, 1996).

Anthony Giddens, Kapitalisme dan Teori Sosial Modern: Suatu Analisis Karya-Karya Tulis Marx, Durkheim dan Max Weber, terj. Oleh Soeheba Kramadibrata dari Capitalism and Modern Social Theory: an Alaysis of Writing of Marx, Durkheim and Max Weber (Jakarta: UIP, 1985).

Atabik Ali, Ahmad Zuhdi Muhdlor, Qamus Krapyak al-Ashri ArabiIndonesi (Yogyakarta: Yayasan Ali Maksum Pondok Pesantren Krapyak Yogyakarta, 1996).

Azyumardi Azra, Jaringan Ulama Timut Tengah dan Kepulauan Nusantara Abad XVII dan XVIII: Melacak Akar-Akar Pembaruan Pemikiran Islam di Indonesia (Bandung: Mizan, 1994).

Fadhlullah Haeri, Belajar Mudah Tasawuf, terj. dari The Element of Sufism oleh Muhammad Hasyim Assagaf (Jakarta: Lentera, 1999), cet. kedua.

Fuad Said, Hakikat Tarekat Naqsabandiyah (Jakarta; Pustaka al-Husna, 1994). Harisuddin Aqib, al-Hikmah: Memahami Teosofi Tarekat Qadiriyah wa Naqsabandiyah (Surabaya: Bina Ilmu, 1998). 
Haryati Soebadio, Catatan Mangenai Metodologi Penelitian dan Filsafat Ilmu Pengetahuan Khususnnya Bidang Sosial-Budaya (Tidak diterbitkan, 1998).

Hawas Abdullah, Perkembangan Ilmu Tasawuf dan Tokoh-tokohnya di Nusantara (Surabaya: al-Ikhlas, tanpa tahun).

Imran Abu Bakar, Disekitar Masalah Thariqat (Naqsabandiyah) (Kudus: Menara Kudus, 1984).

Imam Ahmad b. Hambal, Musnad Imam Ahmad, dalam CD ROM Hadits Versi 102.

J. Spencer Trimingham, Madzhab Sufi, terj. Oleh Luqman Hakim dari The Sufi Orders (Bandung: Pustaka, 1999).

Martin Van Bruinessen, Kitab Kuning Psantren dan Tarekat: Tradisi-Tradisi Islam di Indonesia (Bandung: Mizan, 1999), cet. Ke III. , Tarekat Naqsabandiyah di Indonesia (Bandung: Mizan, 1996). , "The Origin and Development of Sufi Orders (Tarekat) in Shoutheast Asia", dalam Studia Islamika Vol. 1. No. 1, 1994 (Jakarta: PPIM IAIN jakarta).

Mirce Aliade (ed.), The Encyclopedia of Islam, Vol. 14 (New York: Macmillan Publishing Co. 1987).

Nurcholish Madjid, "Islam, Iman dan Ihsan Sebagai Trilogi Ajaran Ilahi” dalam Budhy Munawar Rahman, Kontekstualisasi Donktrin Islam dalam Sejarah (Jakarta: Mizan, 1995). , Bilik-Bilik Pesantren: Potret Sebuah Perjalanan (Jakarta: Paramadina, 1997).

, "Pesantren dan Tasawuf" dalam Dawam Rahardjo (ed.) Pesantren dan Pembaharuan (Jakarta: LP3ES, 1995), Cet. Ke V.

Simuh, Tasawuf dan Perkembangannya dalam Islam (Jakarta: Rajawali Press, 1996.

Zamakhsyari Dhofier, Tradisi Pesantren: Studi tentang Pandangan Hidup Kyai (Jakarta: LP3ES, 1994).

Al-Zarnuji, Ta'lim al-Muta'allim Thariq al-Ta'allum, terj. Oleh Aliy As'ad (Kudus: Menara Kudus, 1978). 